\title{
Significance of Emotional Intelligence in the Era of Artificial Intelligence: A Study on the Application of Artificial Intelligence in Financial and Educational Services Sector
}

\author{
Y Kalyani* and Madhura Ayachit ${ }^{\dagger}$
}

\begin{abstract}
Artificial Intelligence (AI) is the cognitive ability of a computer or machine to think and learn. It is imperative to evaluate the extent to which the Artificial Intelligence (AI) can integrate Emotional Intelligence (EI) which is being posited as a facilitator of enhancing millennial engagement. This study is undertaken with two objectives: 1) exploring the extent of use of Artificial Intelligence (AI) in financial services and 2) examining $\mathrm{AI}^{\prime} \mathrm{s}$ role in enhancing a student's experience in learning activities. The methodology of the study is mainly exploratory. The study brings forth certain significant implications of the future of skill development and the ethical issues that require deliberation for purposes of legislation and drafting of public protection policies.
\end{abstract}

Keywords: Emotional Intelligence, Artificial Intelligence, Cognitive Behaviour

\section{Introduction}

Artificial Intelligence is dealt with extreme caution in the world of Finance. Several Hollywood sci-fi movies have depicted how a computer or robot brings forth ultimate catastrophe for the human

\footnotetext{
* St. Francis College for Women, Hyderabad, India; kalyani.yellapantula@gmail.com

† St. Francis College for Women, Hyderabad, India; madhura.ayachit@gmail.com
} 
race. However, surreptitiously, artificial intelligence has become an important aspect of our daily lives. From identifying spam in Gmail accounts to scanning faces, recognising emotions and understanding our needs by recognising the human language, it is making inroads into our everyday lives, often questioning the necessity of human presence for the said jobs that were previously done by humans. This fear of disruption permeates the customers and the service providers alike. It is imperative to closely explore the extent of its use, limitations and the ways in which it can augment human intelligence.

Human intelligence depends on the five senses as inputs and brain processing. Artificial intelligence, on the other hand, can have an enhanced input process that includes and extends human capabilities. It is possible to train machines with cognitive behaviour. However, we would still need the human interface to do this job. Hence, it may be concluded that there is a need for integrating emotional intelligence and artificial intelligence for enhancing user experiences. This is more evident in the hi-touch industries.

In a hi-touch industry like Banking and Financial Service Industry (BFSI), the presence of artificial intelligence is rapidly changing the face of the industry. It is bringing a paradigm shift in the way processes are tackled. Globally and also in India, the thrust has been on digitalisation and open banking, making it imperative for all players and stakeholders to adapt $\mathrm{AI}$ in the business processes previously handled by human resource. The pressure on costs and decreasing margins also contribute to the emergence of artificial intelligence. In the educational sector, the need of the student to keep up with the recent trends in the subjects that are not curriculum-based drive the virtual learning portals. The user of virtual portals could be motivated by knowledge acquisition and not a certification and which could be seen as a motivator for facilitating the platforms of learning. A tech-savvy generation or a tech-dependent population realises the importance of the need for emotional intelligence in achieving sustainable satisfaction in the long run. Hence, a study towards augmenting AI with EI is necessary to keep the millennial engaged and address the questions of higher satisfaction levels. 


\section{Objectives of the Study}

1. To study the application of Artificial Intelligence in Financial Services

2. To study the role of Artificial Intelligence in imparting education to learners

3. To understand the significance of Emotional Intelligence in the era of Artificial Intelligence

\section{Scope of the Study}

The study is confined to two sectors mainly: the Banking and Financial Services Industry (BFSI) and the educational sector. These industries are both hi-touch industries as well as spaces where artificial intelligence has already made its presence felt. The study is mainly exploratory in nature as it explores the extent of use of Artificial Intelligence in these areas.

\section{Research Methodology}

The study is both explorative and descriptive. Secondary sources of data have been used to study the application of artificial intelligence in the BFSI. The sources include mainly surveys and studies conducted by government and non-government organisations, reports and articles in newspapers and magazines. A structured questionnaire was used to study the role of artificial intelligence in educational services. This was distributed among 107students consisting mainly of UG students and PG students. Hypothesis on factors affecting learners' perception towards higher education and adoption of virtual courses was framed (Table 5). The data was analysed using graphs, descriptive statistics and Chisquare tests.

\section{Review of Literature}

The word Artificial Intelligence was first used and coined by John Mc Carthy in 1956. The World Economic forum report prepared in collaboration with Deloitte treats the advent of AI as the next disruption in the banking sector. The report predicts three 
outcomes - traditional delivery channels will be replaced, concentration of services regionally due to technical and regulatory capabilities and finally dependence of financial services on hi-tech institutions. The need for reskilling is also felt as the total human workforce is predicted to reduce to $48 \%$ by 2025 while most of the jobs will be taken over by machines (World Economic Forum., 2018). The destabilisation in the industry leading to the extinction of firms that are not capable of upgrading their business models could be inevitable as well. Deloitte in association with Confederation of Industry brought out a report "Banking Future 2020". The report identified two areas - Blockchain technology and Robotic process automation. The report also voices concerns over the risks due to such high use of technology (Confederation of Indian Industry, 2016). During September 2018, NASSCOM in collaboration with KPMG came out with a report tracing the development of trends in Fintech advancement in the financial services. The report highlights some facts- Indian Fintech market has witnessed massive investments with 31 deals in the second quarter of 2018, globally, spending on AI expected to reach USD 19.1 billion of which banking sector will account for $17 \%$., and the transition from low-impact rule-based model to high impact cognitive and predictive processes (NASSCOM, 2018). PWC also in its report "Retail Banking 2020-evolution or revolution" warns about the technological high tide that may lead to the sinking of many banks if they do not harness the technological revolution (Schwartz, 2019). The research report approved by Autonomous-a financial research firm says that banks will be saving immensely- to the tune of 1 trillion \$- by replacing the front office and back office processes with AI1. This gives us an idea of why the margin stressed banking firms would run behind the explosion. Towards achieving this end, some of the AI initiatives taken by top Indian Banks (Baruah, 2018) are the following:

a) State Bank of India employs cameras which have software that scans the facial expression of the customer receiving service to assess the quality of the service and the satisfaction level of the customer in real time. The bank for ethical reasons clarifies that this is only to assist in the training of the staff. 
b) Chatbots-Using the NLP or natural language processing and other sophisticated AI tools help the customer with day to day banking processes. There are around 5 versions of these applications presently used by various banks globally.

c) Software robots - This is known to be used by ICICI bank across its branches. These are systems configured to capture millions of transactions from multiple platforms across the branches and simultaneously process these for validation, mining as well as to expedite the processes. The bank reports a reduction of response time by $60 \%$ achieving a100\% accuracy as well.

There are several start-up companies that are investing millions of rupees developing $\mathrm{AI}$ with the ability to process credit applications, fraud detection and risk management capabilities. Needless to say, these may be a boon to the Indian banks bogged down with the high incidence of frauds and credit failures. EY global in its survey in 2017 for Fintech adoption, reports that India is leading in the race with $52 \%$ adoption rate as compared to an average of $46 \%$ in the emerging markets. However, the important point to be noted is that it is the money transfer and payment services that have been utilized mostly. These do not reflect the complete gamut of services that artificial intelligence is capable of. The borrowing and lending services on one hand and the financial advisory services on the other however show only $20 \%$ rate of adoption against the $10 \%$ global rate. The survey also points out that the maximum users are the tech literate age group of 18 to 48 (6). The fact that financially excluded Indian population do not fall in this bracket of techliterate should also be noted.

Shiv Kumar Goel and Nihaal Mehta (2017) brings out the reasons for the emergence of $\mathrm{AI}$ in the Indian banking sector. He suggests that the profits and the enhancement of customer experience with the usage are the key drivers. Crispin Coombs (2018) had studied the relevance and role of human financial advisors vis a vis a robot adviser using service encounter theory. He established that the robot adviser augments a human adviser at best and cannot replace a human. Similarly, Zied Mani and Ines Chouk (2018) argue that smart banking has to consider the consumers' concerns to increase adaptability. They established that several factors like a perceived 
security risk, health risk, and most importantly lack of human touch, adversely affect the adaption of smart services. On the other hand, Ginger ZheJin (2017) talked about the challenges faced by firms dealing with big data in protecting the data from misuse. He suggests that without proper regulation in place, the responsibility of the data cannot be established. There have been several studies empirically establishing that the human touch in the financial industry is an essential element.

The study conducted by Hussin, Jusoff, Omar (2008) to evaluate students' perception towards factors determining lecturers' teaching ability, showed that seventeen dimensions, namely: clarity, practicality, exercises, attention, enthusiasm, creativity, feedback, syllabus, motivation, extra reading, availability, technology, punctuality, current issue, approachable, language use, and communication help in differentiating lecturers' teaching performance and students' perceptions of teaching quality. The findings of this study suggest that the lecturers should consider these dimensions during lecturer-student interaction in the classroom. Smart and Cappell (2006, p. 2020) mention that "Learning theory suggests that learning is promoted or enhanced when students are actively involved in the learning, when assignments reflect real-life contexts, and when critical thinking or deep learning is promoted through applied and reflective activities" (Smart \& Cappel, 2006, p. 202). Breaking through faculty resistance to AI involves helping them understand that it will not replace their core responsibilities but instead supplement the work we already do.

According to Zishaan Hayath, an angel investor and a prominent figure in the Indian entrepreneurial ecosystem argues that "Tech is not going to replace teachers anytime soon. As per a report by Google and KPMG, the ed-tech industry in India is expected to grow 8 times between 2016 and 2021 to $\$ 2$ billion. It will be the fastest growing market in the world. The role of teachers will change to facilitators for more effective learning, driven and delivered by learning app ecosystems". 
Technology, understood in these aspects, benefit in two ways:

- Teachers are not in the capacity to solve learner's doubts round the clock, whereas, technology can.

- Technology amplifies the effect of teachers. Without limiting to the seats in the classroom, a good teacher can reach out to millions of students.

- Average time spent by a user on ed-tech apps:

- 10-20 minutes on global apps like Khan Academy and Coursera

- 40-50 minutes on local ones like Byju's

○ 90 minutes a day on Toppr

- Younger students spend more time with videos and passive learning modes

- Older students spend more time on active learning, such as problem-solving and clearing doubts

Table1 shows examples of the use of AI and Chatbots in Education. As more and more colleges and universities adopt AI and chatbots in education, it will facilitate a superior classroom environment. It will enhance the learning experience and develop vision, resilience and inquisitiveness among the students (Singh, 2018). Emotional Intelligence is a key factor in the customer relationship for the services sector. It is observed that the interactions of the sales personnel or the front office staff are driven by particular emotions that bring out customer satisfaction levels or outcomes. These, in turn, are picked up by the back office moderators with the customers and that in turn sets the organizational performance in customer satisfaction (Keareney et al., 2017). Hence, if the tasks hitherto performed by people are entrusted to artificial intelligence, there may be a drop in customer satisfaction levels. The application so far in the hi-touch industries has been to augment or to enhance the customer satisfaction levels by mimicking the emotions played by humans in their interactions. There is very less literature in the area of customer satisfaction and perception of AI. 
Table 1: Examples of Use of AI and Chatbots in Education

\begin{tabular}{ll}
\hline Chatbot Name & \multicolumn{1}{c}{ Benefits } \\
\hline Botsify & $\begin{array}{l}\text { The topic is presented to students in the form of } \\
\text { text, images, videos, quizzes. Teachers can easily } \\
\text { monitor a student's performance. }\end{array}$ \\
CourseQ & $\begin{array}{l}\text { Easy communication platform for both teachers } \\
\text { and students. Enhances student engagement }\end{array}$ \\
Hubert & $\begin{array}{l}\text { The smart Feedback mechanism is provided } \\
\text { EnatchBot }\end{array}$ \\
& $\begin{array}{l}\text { teachers } \\
\end{array}$
\end{tabular}

\section{Data Analysis and Interpretation}

The demographic profile of the primary data sample is presented in Table 2.

Table 2: The demographic profile of the sample

\begin{tabular}{|c|c|c|c|c|c|c|}
\hline \multicolumn{2}{|c|}{ Age (years) } & \multicolumn{3}{|c|}{ Gender } & \multicolumn{2}{|c|}{ Occupation } \\
\hline $15-20$ & $45 \%$ & Male & Female & $90 \%$ & Student & $91 \%$ \\
\hline $20-25$ & $52 \%$ & \multicolumn{3}{|c|}{ Qualification } & Employed & $8 \%$ \\
\hline $25-30$ & NIL & Undergraduate & $67 \%$ & & Business & $1 \%$ \\
\hline $30-35$ & $1 \%$ & Graduate & $14 \%$ & & & \\
\hline $\begin{array}{l}\text { Above } \\
35\end{array}$ & $2 \%$ & Postgraduate & $19 \%$ & & & \\
\hline
\end{tabular}

I. Awareness regarding the virtual learning portals $-60 \%$ of the respondents is aware of various virtual learning portals like Coursera, Khan Academy, MIT Open Course Ware, MOOC, EdX, Meritnation, GradeUp, Byju's, Marios Tutoring, Superprofs. The majority of respondents (40\%) are aware of Khan Academy.

II. Choice of Virtual courses and types of learners -It is observed from the analysis of the types of learners choosing virtual courses through cross-tabulation (Table 3) that it is the 'Self-learners' $(13 \%)$ who primarily have opted for virtual learning courses, followed by Curious learners $(8 \%)$ and those who learn through questioning $(8 \%)$. This brings out the significance of Artificial Intelligence in the category of understanding self-learners and curious learners. At the 
same time, it is also observed that the learners who learn through questioning also seek AI, indicating that AI has the possibility of complementing EI.

Table 3: Analysis of types of learners who have availed virtual learning courses

\begin{tabular}{|l|c|c|c|c|c|c|c|}
\hline & $\begin{array}{c}\text { Curious } \\
\text { Learn } \\
\text { ers }\end{array}$ & $\begin{array}{c}\text { Self - } \\
\text { Learn } \\
\text { ers }\end{array}$ & $\begin{array}{c}\text { Look for } \\
\text { Value } \\
\text { Additions }\end{array}$ & $\begin{array}{c}\text { Learning } \\
\text { through } \\
\text { Questioning }\end{array}$ & $\begin{array}{c}\text { Peer } \\
\text { Group } \\
\text { Learning }\end{array}$ & $\begin{array}{c}\text { Curriculum- } \\
\text { Based } \\
\text { Learners }\end{array}$ & Total \\
\hline $\begin{array}{l}\text { Availed } \\
\text { virtual } \\
\text { learning } \\
\text { courses }\end{array}$ & $8 \%$ & $\mathbf{1 3 \%}$ & $6 \%$ & $8 \%$ & $2 \%$ & $4 \%$ & $40 \%$ \\
\hline $\begin{array}{l}\text { Did not } \\
\text { avail } \\
\text { any }\end{array}$ & $13 \%$ & $13 \%$ & $5 \%$ & $13 \%$ & $6 \%$ & $9 \%$ & $60 \%$ \\
\hline Total & $21 \%$ & $26 \%$ & $11 \%$ & $21 \%$ & $11 \%$ & $13 \%$ & $100 \%$ \\
\hline
\end{tabular}

III. Reasons to avail virtual learning courses - It is observed (Figure 1) that the majority of learners availed virtual course as AI offers the convenience to learners to do things at their pace. It also reveals the fact that Education - a high touch industry fails to offer broad topics of learners interests in the curriculum.

\section{Reasons to avail virtual learning courses}

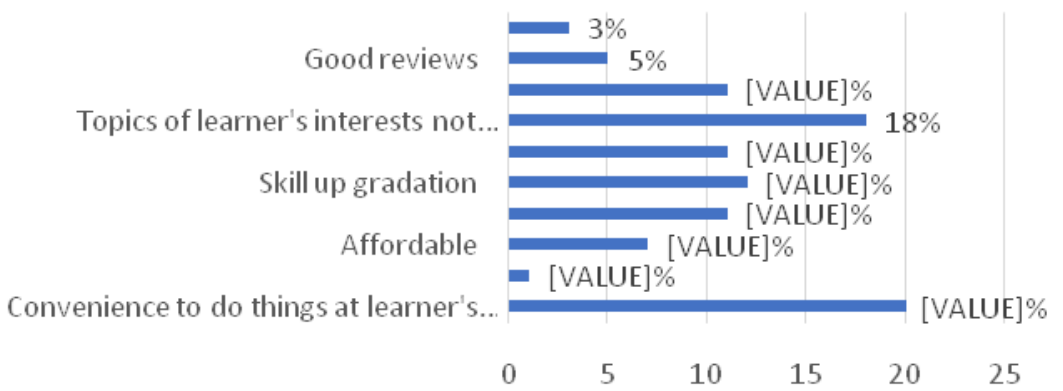

Fig 1: Analysis of reasons to avail virtual learning courses

IV. Attributes to quality education - 'Ability to excel' has the highest mean score (Table 4) indicating that it is the most significant attribute of quality education. At the same time, it is observed that there is a meagre difference in mean 
scores for the rest of the attributes which means - thorough subject knowledge, employability skill development, ability to stay relevant in the era of technology and holistic personality development are equally significant parameters of quality education.

Table 4: Perception towards Attributes of Quality Education

\begin{tabular}{lc}
\hline \multicolumn{1}{c}{ Attributes of Quality Education } & Mean Score \\
\hline Thorough Subject Knowledge & 3.81 \\
Holistic Personality Development & 3.72 \\
Develop Employability Skills & 3.79 \\
Develop the ability to stay relevant in the era of & 3.73 \\
technology & \\
Ability to excel & 3.93 \\
\hline
\end{tabular}

V. Factors affecting learners' perception of higher education and the adoption of virtual courses - Table 5 shows the implications of the various hypothesis.

Table 5: Hypotheses to test the relationship between the various factors affecting the perception of learners' towards higher education

\begin{tabular}{|c|c|c|c|}
\hline Sr.No. & Hypothesis & P - Value & Decision \\
\hline 1 & $\begin{array}{l}\text { There is no difference in } \\
\text { the awareness of virtual } \\
\text { learning portals amongst } \\
\text { the respondents of varying } \\
\text { age groups }\end{array}$ & 0.0385 & Reject \\
\hline 2 & $\begin{array}{l}\text { There is no difference in } \\
\text { the perception of } \\
\text { respondents of varied } \\
\text { learning stages towards the } \\
\text { importance of teacher- } \\
\text { student relationship }\end{array}$ & 0.0653 & Accept \\
\hline 3 & $\begin{array}{l}\text { There is no difference in } \\
\text { the perception of } \\
\text { respondents of varied } \\
\text { learning stages towards the } \\
\text { importance of technical } \\
\text { aids in teaching }\end{array}$ & 0.6592 & Accept \\
\hline 4 & $\begin{array}{l}\text { There is no difference in } \\
\text { the perception of } \\
\text { respondents of varied age } \\
\text { groups towards virtual }\end{array}$ & 0.7416 & Accept \\
\hline
\end{tabular}




\begin{tabular}{|c|c|c|c|}
\hline & $\begin{array}{l}\text { learning courses role of } \\
\text { bridging the gap between } \\
\text { industry and academia }\end{array}$ & & \\
\hline 5 & $\begin{array}{l}\text { There is no difference in } \\
\text { the belief of respondents of } \\
\text { varying age groups that } \\
\text { virtual learning courses } \\
\text { offer courses at no hidden } \\
\text { costs }\end{array}$ & 0.6086 & Accept \\
\hline 6 & $\begin{array}{l}\text { There is no difference in } \\
\text { the perception of } \\
\text { respondents of varied age } \\
\text { groups towards the need } \\
\text { of emotional connect of the } \\
\text { teacher with the student to } \\
\text { mould the learner into a } \\
\text { citizen of good values }\end{array}$ & 0.0487 & Reject \\
\hline
\end{tabular}

Results are interpreted as follows. Since the P-value is less than the significance level (0.05), the Null hypothesis is rejected. This shows,

a. There is a difference in the awareness of virtual learning portals amongst the respondents of varying age groups.

b. There is a difference in the perception of respondents of varied age groups towards the need of emotional connect of the teacher with the student to mould the learner into a citizen of good values.

However, there is no difference observed in the perception of respondents of varied learning stages towards acknowledging the importance of teacher-student relationship and the use of technical aids. Irrespective of different age groups, all respondents believe in the significance of AI in bridging the gap between industry and academia and are of the opinion that the virtual courses are offered at no hidden costs.

VI. Perception towards teaching mode in future - Table 6 shows the various learners' and their perception towards teaching in the future. $85 \%$ of total respondents are of the opinion that virtual courses will complement the existing mode of teaching methodology in the coming years. This brings out the relevance of EI in the era of AI. 
Table 6: Perception of various types of learners towards teaching mode in future

\begin{tabular}{|l|c|c|c|c|c|c|c|}
\hline & $\begin{array}{c}\text { Curi } \\
\text { ous } \\
\text { Learn } \\
\text { ers }\end{array}$ & $\begin{array}{c}\text { Self } \\
\text { Learners }\end{array}$ & $\begin{array}{c}\text { Look } \\
\text { for } \\
\text { value } \\
\text { additions }\end{array}$ & $\begin{array}{c}\text { Learning } \\
\text { through } \\
\text { question } \\
\text { ing }\end{array}$ & $\begin{array}{c}\text { Peer } \\
\text { group } \\
\text { learn } \\
\text { ing }\end{array}$ & $\begin{array}{c}\text { Curri } \\
\text { culum- } \\
\text { based } \\
\text { learners }\end{array}$ & Total \\
\hline $\begin{array}{l}\text { Virtual } \\
\text { ourses will } \\
\text { complemen } \\
\text { t the } \\
\text { existing } \\
\text { mode of } \\
\text { teaching } \\
\text { method } \\
\text { logy }\end{array}$ & $19 \%$ & $19 \%$ & $12 \%$ & $19 \%$ & $6 \%$ & $10 \%$ & $85 \%$ \\
\hline $\begin{array}{l}\text { Virtual } \\
\text { ourses } \\
\text { will/ } \\
\text { should } \\
\text { replace } \\
\text { egular } \\
\text { teaching } \\
\text { mode in } \\
\text { coming } \\
\text { years }\end{array}$ & $1 \%$ & $6 \%$ & $2 \%$ & $2 \%$ & $2 \%$ & $2 \%$ & $15 \%$ \\
\hline Total & $20 \%$ & $25 \%$ & $14 \%$ & $21 \%$ & $8 \%$ & $12 \%$ & $100 \%$ \\
\hline
\end{tabular}

\section{Conclusion}

To conclude the above discussion, the Financial Services industry is rapidly changing its face. The concerns expressed and felt are mainly with respect to the security aspect of handling such large amounts of data. The protection of customer is of utmost importance. The use of AI has been primarily focussed on the applications alongside building the human interface. Thus, the full impact of AI on customer perception is still not known. Several studies and theories have suggested the co-existence of both for the maximisation of customer satisfaction. In the educational sector, online portals are gaining popularity among the student population. They are mainly being used to complement traditional classroom teaching. The study brought out that irrespective the stage of the learner, $85 \%$ of the sample felt that AI cannot replace the traditional teacher-student relationship in the future. The existing gap between academia and industry is also one of the reasons for the use of virtual learning platforms. Therefore, one 
must compliment the other. Thus, it can be concluded that in both financial as well as educational service sectors emotional intelligence and artificial intelligence must co-exist for the best possible outcomes.

A few tentative suggestive measures can be offered on the basis of the study. The challenges that the innovations face are pertaining to transparency, accountability, fairness to all and ensuring the smooth transition in the reskilled workforce. The regulators should utilise effective measures to handle big data. The banks and financial institutions have to tread carefully as the full impact of the $\mathrm{AI}$ is still to be seen. Continuous customer feedbacks are necessary to keep in check any adverse impact on adaption that may lead to a negative effect on revenue lines. The educational institutions will benefit if they enter into the virtual platforms along with certifications for more sustainability and survival. Also, the curriculum must be more in line with industry requirements for better customer satisfaction.

\section{References}

Artino, K. A. (2011). Undergraduate students perceptions of a quality online course: online experience versus no online experience (Doctoral dissertation, University of Akron).

Autonomous Next. (2019). Augmented Finance \& Machine Intelligence. Retrieved from https://next.autonomous.com/augmented-financemachine-intelligence/

Baruah, A. (November 29, 2018). AI applications in top four Indian Banks. Retrieved from https://emerj.com/ai-sector-overviews/aiapplications-in-the-top-4-indian-banks /

Confederation of Indian Industry. (2016). Banking on Future - Vision 2020. Deloitte- colloquium thought paper. Retrieved from https://www2.deloitte.com/content/dam/Deloitte/in/Documents/f inancial-services/in-fs-deloitte-banking-colloquium-thoughtpapercii.pdf

Coombs, C., \& Redman, A. (2018). The impact of robo-advice on financial advisers: a qualitative case study. Retrieved from https://dspace.lboro.ac.uk/dspacejspui/bitstream/2134/32441/1/The \%20impact $\% 20$ of \%20roboadvice $\% 20$ on $\% 20$ financial $\% 20$ advisors $\% 20$ Final $\% 20$ \%20revised \%20March\%202018.pdf 
EY Global. (2017). Four themes driving fin tech adoption by consumers. Retrieved from https://www.ey.com/en_gl/banking-capitalmarkets/four-themes-driving-fintech-adoption-by-consumers

Goel, S.K., \& Mehta, N. (2017). A Survey on the role of artificial intelligence in FinTech, 5(6), 11809-11813.

Hussin, Z., Jusoff, K., \& Wan-Omar, M. (2008). Perception of Students Teaching Quality Determinants and Effectiveness. Asian Social Science, 4(12), 113-117.

Jin, G. Z. (2018). Artificial Intelligence and Consumer Privacy (No. w24253). National Bureau of Economic Research. Accessed on 11/04/2018 at https://www.nber.org/chapters/c14034.pdf

Kearney, T., Walsh, G., Barnett, W., Gong, T., Schwabe, M., \& Ifie, K. (2017). Emotional intelligence in front-line/back-office employee relationships. Journal of Services Marketing, 31(2), 185-199.

Mani, Z., \& Chouk, I. (2018). Smart banking: Why it's important to take into account consumers' concerns? Retrieved from https://halshs.archives-ouvertes.fr/halshs-01678806/document

NASSCOM. (September 2018). Fintech in India - Powering Digital economy. Retrieved from https://www.nasscom.in/knowledgecenter/publications/fintech-india-\%E2\%80\%93-powering-digitaleconomy

Retail Banking 2020. (2017). Evolution or revolution.

Schwartz, N. (2019). How artificial intelligence and virtual reality are changing higher ed instruction. Retrieved from https://www.educationdive.com/news/how-artificial-intelligenceand-virtual-reality-are-changing-higher-ed-inst/541247/

Singh, R. (2018). AI and Chatbots what does the future holds? -chatbots magazine. Retrieved from https://chatbotsmagazine.com/ai-andchatbots-in-education-what-does-the-futurehold-9772f5c13960

Times of India. (April 1, 2018). From Startup Stories.

World Economic Forum. (August 2018). The new physics of financial services-how artificial intelligence is transforming the financial ecosystem. Retrieved from https://www.weforum.org/reports/thenew-physics-of-financial-services-how-artificial-intelligence-istransforming-the-financial-ecosystem 